\title{
Factors that Affect Cycling Transportation Mode for Postgraduate Students at Universiti Kebangsaan Malaysia by Logit Method
}

\author{
(Faktor-faktor yang Memberi Kesan Mod Pengangkutan Berbasikal untuk Pelajar Pasca Siswazah di \\ Universiti Kebangsaan Malaysia dengan Kaedah Logit) \\ Sahar Abd Ali Dawood* \& Riza Atiq bin O.K. Rahmat
}

\begin{abstract}
The main aim of this study is to investigate the factors that affect cycling transportation mode and give suggestions to encourage students to use these facilities to decrease the use of motorized transportation. Firstly we chose the Universiti Kebangsaan Malaysia (UKM) campus as an example for our study which focused on shifting from motorized transport to non-motorized especially to cycling transport. Our study involved conducting a survey on postgraduate students at 1st semester (2013-2014). A total of 169 questionnaires were distributed personally inside the campus and interviews were done with the students. Our survey showed that the majority of postgraduate students were tending to use car with percentage of $45.5 \%$ and $38.4 \%$ prefer using the bus followed by $12.4 \%$ using motorcycle and the least percentage using bicycles with percentage of $3.5 \%$. The most effective factor in shifting postgraduate students who use cars and motorcycles to use bicycles is imposing fees on parking inside UKM and limiting the space for parking. The decrease in the number of buses inside campus and imposing fees on buses have high effectiveness in switching students who use the bus to cycling transportation.
\end{abstract}

Keywords: Shifting; cycling; postgraduate students; logit method; UKM

\section{ABSTRAK}

Tujuan utama kajian ini adalah untuk meninjau faktor-faktor yang memberi kesan kepada mod pengangkutan berbasikal dan memberikan cadangan-cadangan untuk menggalakkan pelajar menggunakan kemudahan-kemudahan tersebut bagi mengurangkan penggunaan pengangkutan bermotor. Pertama sekali kami memilih kampus Universiti Kebangsaan Malaysia (UKM) sebagai contoh dalam kajian kami, yang memberi tumpuan kepada peralihan daripada pengangkutan bermotor kepada yang bukan bermotor, terutama sekali kepada pengangkutan berbasikal. Kajian kami telah melibatkan tinjauan ke atas pelajar pasca siswazah di semester 1 (2013-2014). Sebanyak 169 soal selidik telah diedarkan secara sendiri di dalam kampus dan temu bual telah dilakukan dengan para pelajar. Kaji selidik kami menunjukkan bahawa majoriti pelajar pasca siswazah telah cenderung untuk menggunakan kereta dengan peratusan 45.5\% dan 38.4\% cenderung menggunakan bas diikuti oleh 12.4\% menggunakan motosikal, manakala peratusan yang paling kurang ialah yang menggunakan basikal dengan peratusan 3.5\%. Faktor yang paling berkesan bagi menganjak pelajar pasca siswazah yang menggunakan kereta dan motosikal untuk menggunakan basikal ialah mengenakan bayaran di tempat letak kereta di dalam UKM dan menghadkan ruang tempat letak kereta. Pengurangan jumlah bas di dalam kampus dan mengenakan yuran ke atas bas mempunyai keberkesanan yang tinggi bagi mengalihkan pelajar yang menggunakan bas kepada pengangkutan berbasikal.

Kata kunci: Peralihan; berbasikal; pelajar pasca siswazah; kaedah logit; UKM

\section{INTRODUCTION}

Cars are the second most common mode of transportation in Malaysia. The rapid increase in the use of personal transportation has its roots in the weak public transport system in Malaysia (Yazida et al. 2011). Non-motorized transportation (NMT) includes all forms of travel that do not rely on an engine or motor for movement, including walking, cycling, and using small-wheeled transport (e.g., skates, skateboards, push scooters, and hand carts) and the wheelchair (Xinhua News Agency 2007). Cycling not only decreases the problems that cause global warming, such as pollution and increasing energy usage, but also improves the health and well-being of individuals (Austroads 2005).

In addition to sports and other physical activities, regularly cycling to work (and to school and other regular destinations) is one of the most effective ways to improve health. Several scientific studies that assess the effects of bicycling on levels of physical activity, obesity rates, cardiovascular health, and morbidity have shown that bicycling is healthy (Anderson et al. 2000; Bassett et al. 2008). Modern people have high levels of mobility, travel often over long distances, and go on complex trips (i.e., they undertake several activities in one trip) (Jensen 1999; 
Knowles 2006). These changes exert various negative effects on society and the environment, such as congestion, air pollution, noise, vibrations, health problems (e.g., due to a lack of physical activity or the inhalation of polluting agents), accidents, growing infrastructure costs, and accessibility problems for low-income groups.

Cycling is also a space- and energy-efficient mode of transport that is affordable for many households (Pucher et al. 1999; Piet 2001; Gatersleben and Appleton 2007; Woodcock et al. 2007). Thus, a substantial shift from using cars to using bicycles can reduce urban congestion and the environmental harm caused by air and noise pollution.

The aim of this study is to determine the factors effecting on transport inside UKM and its effect on the transportation in UKM.

\section{LITERATURE REVIEW}

In 2009, the Irish government introduced a tax relief scheme whereby employees can purchase a bicycle through their employer. This scheme was introduced to encourage workers to regularly cycle to work and to promote sustainable transport. A study was conducted to show how individuals who had never owned a bicycle in the past five years changed their perceptions of cycling and improved accessibility to bicycles and cycling after using this scheme. The results demonstrate how successful the scheme has been in improving perceptions of cycling, especially among individuals who have not owned a bicycle in several years. In Ireland, as in other countries, young males are traditionally likely to commute by bicycle. Improving the attractiveness and accessibility of cycling to females and older-age groups is a key policy area for developing cycling in Ireland. That study demonstrated that the scheme has successfully encouraged many females and older-age groups to cycle regularly. Similar cycle-to-work schemes have been implemented in other countries, and the study quantified several benefits from the Irish experience. In Ireland, young males are traditionally likely to commute by bicycle. Improving the attractiveness of cycling to females and older-age groups is a key policy area for developing cycling. That study demonstrated that the scheme has successfully encouraged many females and older-age groups to cycle regularly. Similar cycle-to-work schemes have been implemented in other countries, and the study quantified several benefits.

In terms of accessibility, the scheme has successfully encouraged individuals to cycle regularly for work and nonwork trips (Caulfield and Leahy 2011). Walsh et al. (2008) proposed that such a view fails to consider such factors as the increase in carbon dioxide exhaled as a result of increased physical activity or the emission of the manufacture of bicycles. The study estimated emission factors for various forms of commuter transport in Ireland that allow comparison against emissions from cycling. When indirect energy is considered, the results indicate that a cyclist that commutes an equivalent distance to work releases a nearly equal amount of carbon dioxide to that attributed to a passenger of an electrically propelled train at full occupancy during peak service times. Traveling by bicycle is less carbon-intensive than traveling at off-peak times. Transport by car and sports utility vehicle is the most carbon-intensive of the commuter modes of transport studied; however, traveling in a fully occupied car has an emission factor close to that of off-peak bus transport.

\section{METHODOLOGY}

Figure 1 shows the methodological analysis and the processes followed to achieve the goals of this research and show the concept used for data collection and interpretation. A survey was conducted to examine the impacts of the Cycle Scheme. The Microsoft excel 2010 model as well as logit choice model was used to analyze the data. The framework for developing the models on car user's mode choice behavior and potential mode shift from motorize transport to cycling transport is as illustrated below.

\section{DATA COLLECTION}

Stated Preference (SP) Stated preference (SP) methods are widely used in travel behavior research and Practice to identify behavioral responses to choice situations. An attitudinal survey asks the respondents for their response to various situations (e.g. would they switch to cycle if the service improved) and /or to rate their liking for various changes. Hypothetical choice surveys require the respondents to choose between hypothetical alternatives with varying attributes, for data with which to develop behavioral models.

Revealed Preference (RP) RP data were collected on socioeconomic, mode attributes and trip characteristics.The socioeconomics data included the respondents' income, age, gender, vehicle ownership, and household income, total members in the household and their occupations and education levels. Trip information (both mode attributes and trip characteristics') included the purpose, mode of travel and total trip.

Sample Size The credibility of data collected depends on the sample size. Sample size helps to correlate the fluctuation that exist different sample. The sample reflects the characteristics of the population from which postgraduate student in Universiti Kebangsaan Malaysia preferential choice to the available transportation medium is drawn. The probability methods used for data collection include random sampling, systematic sampling, and stratified sampling. The difference between the sample and the real population is called the sampling error. If the sampling error is $\pm 3 \%$, the confidence level involves the risk we are willing to accept that our sample is within the average or "bell curve" of the population. A confidence level of $90 \%$ means that, were the population 


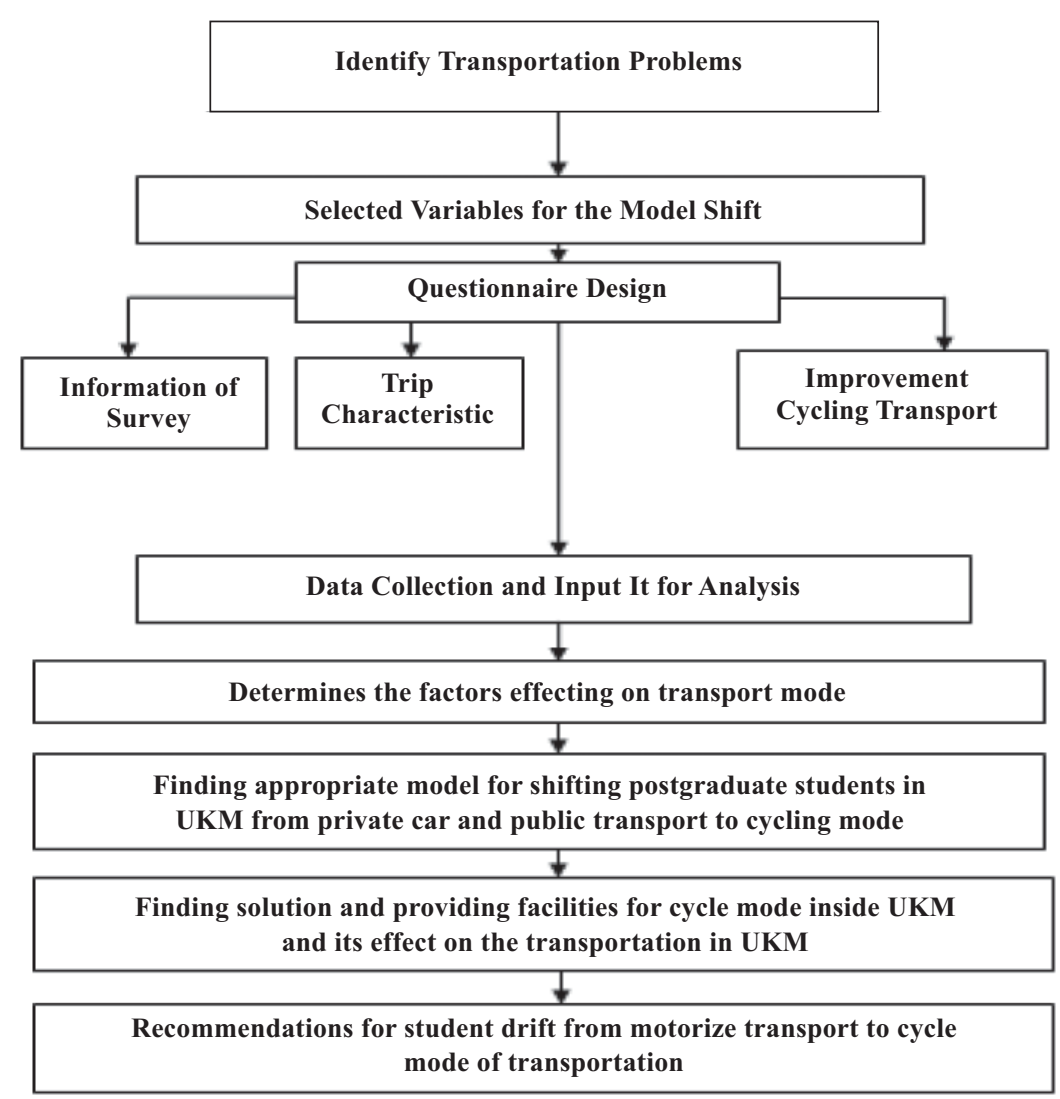

FIGURE 1. Design illustration of strategies used for data collection and analysis

sampled 100 times in the same manner, 90 of these samples would have the true population value within the range of precisions specified earlier, and 10 would be unrepresentative samples. Higher confidence levels require larger sample sizes. Variability is the degree to which the attributes or concepts being measured in the questions are distributed throughout the population (Watson 2001).

Table 1 shows the numbers of sample size with \pm 3 margin of error and as it is illustrated above that the numbers are so high and it will be difficult to collect, therefore $5 \%$ error will be good enough for our survey. We take our sample size according to Table 1 with $\pm 5 \%$ margin of error. From the table at population of 9.000 the sample size needed is 169 at variability of $30 \%$, at population of 10.000 the sample size is 169 at variability of $30 \%$. The total number of the postgraduate students is 9155 , therefore we take the sample size equal to 169 .

\section{LOGIT MODEL}

The logic model was used as a final model to investigate mode choice behavior of travelers to highlight the trend of the travelers when considering their mode of transport (Abdullah 2007). The proposed model used to predict the relationship between dependent variables is evaluated based on the following equation.

$$
y=\frac{1}{1+e^{-f(x)}}
$$

where $f(x)$ is an analytic function in $x$. With this choice, the single-layer network is identical to the logistic regression model. This function has a continuous derivative, which allows it to be used in back propagation. The following functional form is used in this paper to determine the variables where $e$ is Euler's number. For values of $x$, it is in the range of real numbers from $-\infty$ to $+\infty$.

$$
p=\frac{1}{1+D e^{\alpha(\text { variable })}}
$$

\section{LOGIT FUNCTION}

An explanation of logistic regression begins with an explanation of the logistic function:

$$
F=(z) \frac{1}{1+e^{-z}}
$$

The above equation investigates the calibration process based on the values of $D$ and $\alpha$ values which were extracted from ANOVA table using Microsoft Excel. These results applied to the final equation (1) and then the results were 
TABLE 1 . Finding a base sample size with \pm 5 margin of error

\begin{tabular}{|c|c|c|c|c|c|}
\hline & $\begin{array}{c}\text { Sample Size } \\
\text { Variability }\end{array}$ & & & & \\
\hline Population & $50 \%$ & $40 \%$ & $30 \%$ & $20 \%$ & $10 \%{ }^{\mathrm{d}}$ \\
\hline $100^{\mathrm{e}}$ & 81 & 79 & 63 & 50 & 37 \\
\hline 125 & 96 & 93 & 72 & 56 & 40 \\
\hline 150 & 110 & 107 & 80 & 60 & 42 \\
\hline 175 & 122 & 119 & 87 & 64 & 44 \\
\hline 200 & 134 & 130 & 93 & 67 & 45 \\
\hline 225 & 144 & 140 & 98 & 70 & 46 \\
\hline 250 & 154 & 149 & 102 & 72 & 47 \\
\hline 275 & 163 & 158 & 106 & 74 & 48 \\
\hline 300 & 172 & 165 & 109 & 76 & 49 \\
\hline 325 & 180 & 173 & 113 & 77 & 50 \\
\hline 350 & 187 & 180 & 115 & 79 & 50 \\
\hline 375 & 194 & 186 & 118 & 80 & 51 \\
\hline 400 & 201 & 192 & 120 & 81 & 51 \\
\hline 425 & 207 & 197 & 122 & 82 & 51 \\
\hline 450 & 212 & 203 & 124 & 83 & 52 \\
\hline 500 & 222 & 212 & 128 & 84 & 52 \\
\hline 600 & 240 & 228 & 134 & 87 & 53 \\
\hline 700 & 255 & 242 & 138 & 88 & 54 \\
\hline 800 & 267 & 252 & 142 & 90 & 54 \\
\hline 900 & 277 & 262 & 144 & 91 & 55 \\
\hline 1,000 & 286 & 269 & 147 & 92 & 55 \\
\hline 2,000 & 333 & 311 & 158 & 96 & 57 \\
\hline 3,000 & 353 & 328 & 163 & 98 & 57 \\
\hline 4,000 & 364 & 338 & 165 & 99 & 58 \\
\hline 5,000 & 370 & 343 & 166 & 99 & 58 \\
\hline 6,000 & 375 & 347 & 167 & 100 & 58 \\
\hline 7,000 & 378 & 350 & 168 & 100 & 58 \\
\hline 8,000 & 381 & 353 & 168 & 100 & 58 \\
\hline 9,000 & 383 & 354 & 169 & 100 & 58 \\
\hline 10,000 & 385 & 356 & 169 & 100 & 58 \\
\hline 15,000 & 390 & 360 & 170 & 101 & 58 \\
\hline 20,000 & 392 & 362 & 171 & 101 & 58 \\
\hline 25,000 & 394 & 363 & 171 & 101 & 58 \\
\hline 50,000 & 397 & 366 & 172 & 101 & 58 \\
\hline 100,000 & 398 & 367 & 172 & 101 & 58 \\
\hline
\end{tabular}

Source: (Watson 2001). How To Determine a Sample Size

used for model validation according to the following equation (Axler, 2006) and you should write reference.

\section{RESULTS AND DISCUSSION}

FACTORS INFLUENCE ON SHIFTING TO CYCLING FOR CAR AND MOTORCYCLE USERS

If UKM Increased Parking Fees Figure 2 shows that about $10.2 \%$ of postgraduate students would turn to bicycle when UKM impose RM 2 per hour on parking. This percentage continuous in increase when fees increase, until it reach to $95.91 \%$ when the fees reach to RM 20 per hour.

$$
P=\frac{1}{1+8.3325 e^{-0.27419(\text { parking fees per hour })}}
$$

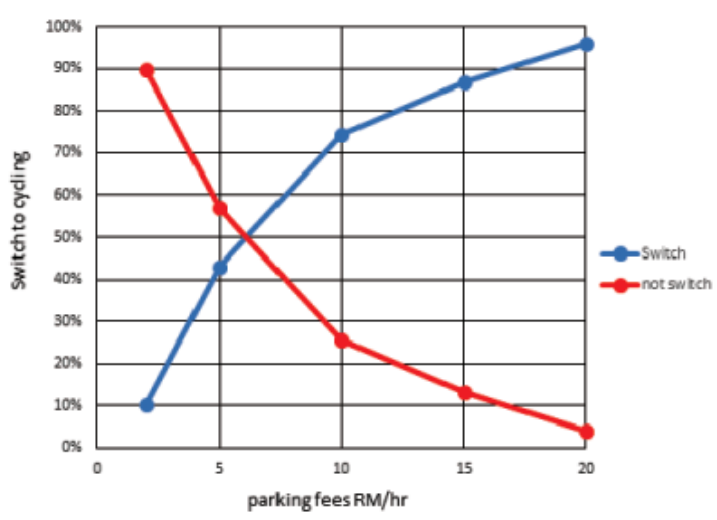

FIGURE 2. Increasing parking fees

Results for the process of calibration comparing with the survey results are indicated in Table $2 \mathrm{a}$. It is as given in the table that the model resulted from ANOVA and regression statistics is highly correlated with survey results obtained from questionnaire and analyzed. The high correlation between survey results and logit model is clarified in Figure 3 where both of the survey results and the modeled one for were increased with the increasing of parking fees per hour.

TABLE 2a. Survey result and data calibration

\begin{tabular}{lccc}
\hline Parking fees & Survey results & $(1-\mathrm{p}) / \mathrm{p}$ & $\operatorname{Ln}(1-\mathrm{p}) / \mathrm{p}$ \\
\hline RM2 & 0.102 & 8.803 & 2.175 \\
RM5 & 0.4285 & 1.333 & 0.287 \\
RM10 & 0.7448 & 0.342 & -1.072 \\
RM15 & 0.8673 & 0.153 & -1.877 \\
RM20 & 0.9591 & 0.042 & -3.170 \\
\hline
\end{tabular}

From this results shown and after regression analyses in excel we got the ANOVA, In $\mathrm{D}=2.120171, \mathrm{D}=8.3325, \alpha=-0.27419$

TABLE $2 b$. Survey results and logit model results

\begin{tabular}{lcc}
\hline Parking fees per hour & Survey results $(\mathrm{P})$ & Logit model \\
\hline RM2 & 0.102 & 0.1719 \\
RM5 & 0.4285 & 0.3209 \\
RM10 & 0.7448 & 0.6506 \\
RM15 & 0.8673 & 0.8800 \\
RM20 & 0.9591 & 0.9665 \\
\hline
\end{tabular}

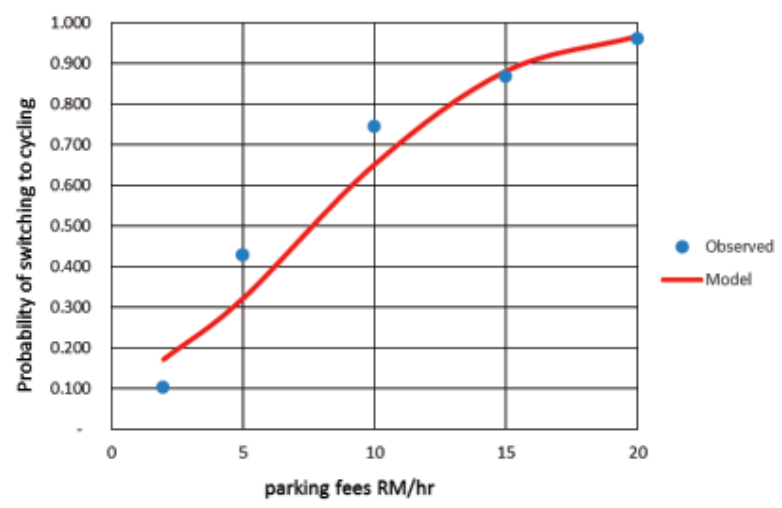

FIGURE 3. Parking fees per hour that will support cycling 
If UKM Limited the Space of Parking If we limit the spaces for parking, students will prefer to shift to cycling by $3.06 \%$ at decreases rate of $10 \%$ and this percentage increased when the reduction increased. In reduction of $50 \%$ around $61.22 \%$ of postgraduate students would like to switch to cycle and when the reduction reaches to $90 \%, 92.85 \%$ of students will leave their cars or motorcycles and change to use bicycle as shown in the figure.

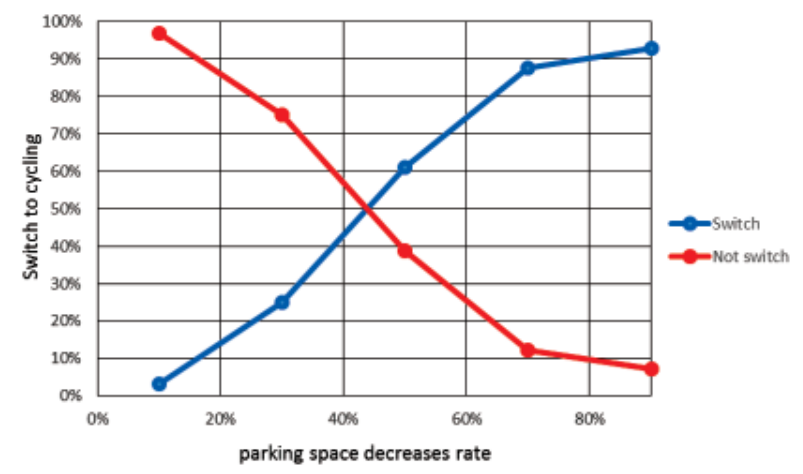

FIGURE 4. Limited the space of parking

$$
P=\frac{1}{1+40.10295 e^{-7.5565(\text { parking space decrease rate })}}
$$

Results for the process of calibration are indicated in Table 3a along with results obtained from survey. It is as given in Table $3 a$ that the model resulted from ANOVA and regression statistics is highly correlated with survey results obtained from questionnaire and analyzed. The high correlation between survey results and Logit model for reduction parking spaces for the private cars is clarified in Figure 5 where both of the survey results and the modeled one showed high agreement from students to be shifted to

TABLE 3a. Survey result and data calibration

\begin{tabular}{lccc}
\hline $\begin{array}{l}\text { Parking space } \\
\text { decreases rate }\end{array}$ & Survey results(P) & $(1-\mathrm{p}) / \mathrm{p}$ & $\operatorname{Ln}(1-\mathrm{p}) / \mathrm{p}$ \\
\hline $10 \%$ & 0.0306 & 31.679 & 3.455 \\
$30 \%$ & 0.2489 & 3.017 & 1.104 \\
$50 \%$ & 0.6122 & 0.633 & -0.457 \\
$70 \%$ & 0.8775 & 0.139 & -1.973 \\
$90 \%$ & 0.9285 & 0.077 & -2.563 \\
\hline
\end{tabular}

From this results shown and after regression analyses in excel we got the ANOVA, ln $\mathrm{D}=3.69145, \mathrm{D}=40.10295, \alpha=-7.5565$.

TABLE 3b. Survey results and logit model results

\begin{tabular}{lcc}
\hline $\begin{array}{l}\text { Parking space } \\
\text { decreases rate }\end{array}$ & Survey results(P) & Logit model \\
\hline $10 \%$ & 0.0306 & 0.05044 \\
$30 \%$ & 0.2489 & 0.1939 \\
$50 \%$ & 0.6122 & 0.5216 \\
$70 \%$ & 0.8775 & 0.8317 \\
$90 \%$ & 0.9285 & 0.9572 \\
\hline
\end{tabular}

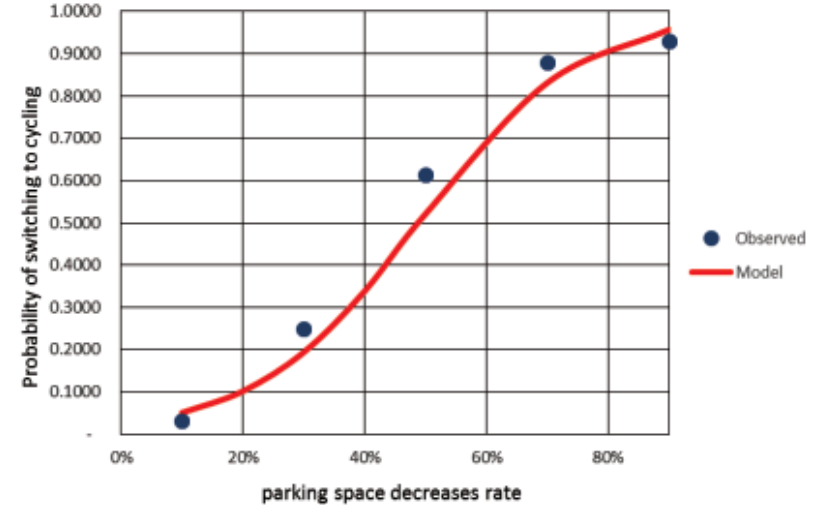

FIGURE 5. Parking space reduction that will support cycling

cycle mode of transportation when the limited parking spaces are increased.

FACTORS INFLUENCE ON SHIFTING TO CYCLING FOR BUS USERS

If UKM Imposed Fees on Bus As the survey results about $38.4 \%$ from the postgraduate students choose bus inside UKM, therefore we suggest to the university to imposed fees on bus to support shifting to cycle. At RM 2 about $4.61 \%$ of postgraduate students will switch while the other students thought that this fee is affordable. This percentage increased when the fees increased. At fee of RM 20 most of postgraduate students would like to change because they feel that this fees is so costly and cannot pay it.

$$
p=\frac{1}{1+21.8401 e^{-0.27893(\text { bus fees) }}}
$$

Results for the process of calibration which then imported to Excel to get the ANOVA are indicated in Table 4a. From ANOVA and Regression table our model got the value of $P$ equals to $(0.005)$ which somehow acceptable to

TABLE 4a. Survey result and data calibration

\begin{tabular}{lccc}
\hline Bus Fees Per Trip & Survey results(P) & $(1-\mathrm{p}) / \mathrm{p}$ & $\operatorname{Ln}(1-\mathrm{p}) / \mathrm{p}$ \\
\hline RM2 & 0.0461 & 20.6919 & 3.0297 \\
RM5 & 0.2920 & 2.4246 & 0.8856 \\
RM10 & 0.3538 & 1.8264 & 0.6023 \\
RM15 & 0.7538 & 0.3266 & -1.1190 \\
RM20 & 0.9230 & 0.0834 & -2.4841 \\
\hline
\end{tabular}

From this results shown and after regression analyses in excel we got the ANOVA. In $\mathrm{D}=3.083749, \mathrm{D}=21.8401, \alpha=-0.27893$

TABLE 4b. Survey results and logit model results

\begin{tabular}{lcc}
\hline Bus Fees Per Trip & Survey results(P) & Logit model \\
\hline RM2 & 0.0461 & 0.07406 \\
RM5 & 0.2920 & 0.15589 \\
RM10 & 0.3538 & 0.4269 \\
RM15 & 0.7538 & 0.7502 \\
RM20 & 0.9230 & 0.9237 \\
\hline
\end{tabular}




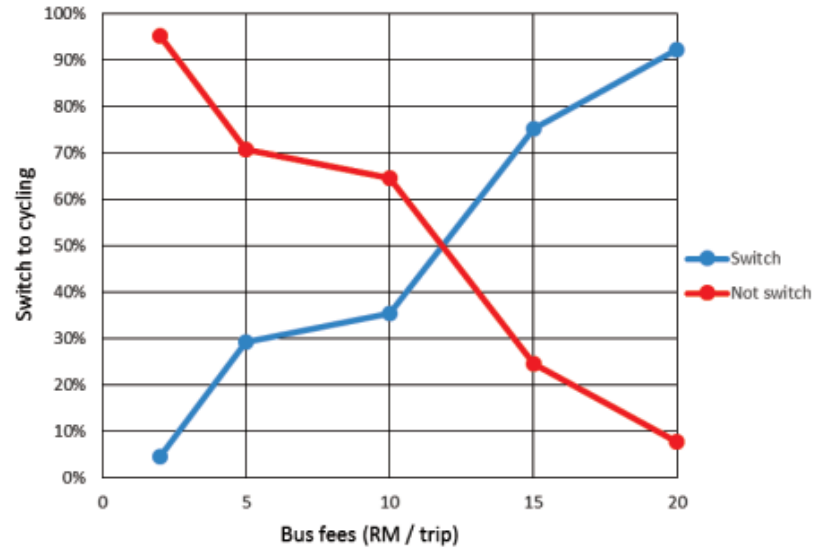

FIGURE 6. Imposing fees on bus

be significant (significant value $<0.05$ ) while is $R$ Square (0.97). The high correlation between survey results and Logit model is demonstrated in Figure 7 where both of the survey results and the modeled were increased with the increasing bus fees.

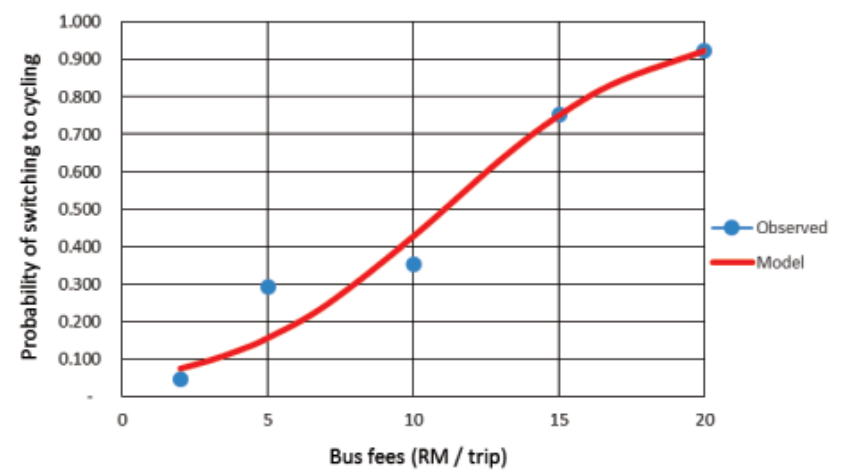

FIGURE 7. Bus fees that will support cycling

Decreased Frequency of Bus Figure 8 shows the results of our suggestion to decrease the number of buses travelling inside the campus it cleared around $15.38 \%$ will agree to shift to cycling if decreases number of buses to $10 \%$, meanwhile $35.38 \%$ will agree to shift if the decreasing rate reaches to $(30 \%)$.when the decreasing rate reaches to $50 \%$, $70 \%$ and $90 \%$ around $58.46 \%, 89.23 \%$ and $95.38 \%$ will shift respectively.

$$
p=\frac{1}{1+11.13951 e^{-6.09215(\text { reduction rate })}}
$$

It is demonstrated from Table 5a that the model used in this study is got the value of $P$ equals to 0.0004 which somehow acceptable to be significant (significant value $<0.05)$. This fact is more identified in Figure 9 which illustrates high correlation between survey results and the modeled one that they showed increasing shifting when reductions of buses increase.

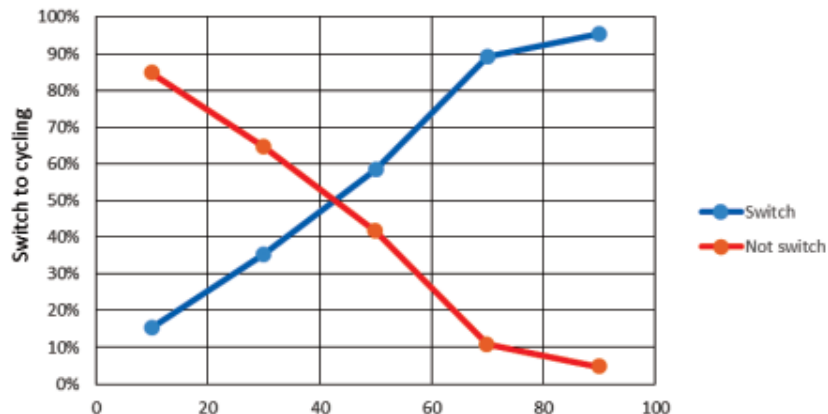

FIGURE 8. Decreasing frequency of bus

TABLE 5a. Survey result and data calibration

\begin{tabular}{lccc}
\hline Reduction rate & Survey results $(\mathrm{P})$ & $(1-\mathrm{p}) / \mathrm{p}$ & $\operatorname{Ln}(1-\mathrm{p}) / \mathrm{p}$ \\
\hline $10 \%$ & 0.1538 & 5.5019 & 1.70509 \\
$30 \%$ & 0.3538 & 1.8264 & 0.60234 \\
$50 \%$ & 0.5846 & 0.7105 & -0.34178 \\
$70 \%$ & 0.8923 & 0.1206 & -2.11527 \\
$90 \%$ & 0.9538 & 0.0484 & -3.02825 \\
\hline
\end{tabular}

From this results shown and after regression analyses in excel we got the ANOVA, ln $\mathrm{D}=2.410499, \mathrm{D}=11.13951, \alpha=-6.09215$

TABLE 5b. Survey results and logit model results

\begin{tabular}{lcc}
\hline Reduction rate & Survey results(P) & Logit model \\
\hline $10 \%$ & 0.1538 & 0.141694 \\
$30 \%$ & 0.3538 & 0.358276 \\
$50 \%$ & 0.5846 & 0.653752 \\
$70 \%$ & 0.8923 & 0.86459 \\
$90 \%$ & 0.9538 & 0.95574 \\
\hline
\end{tabular}

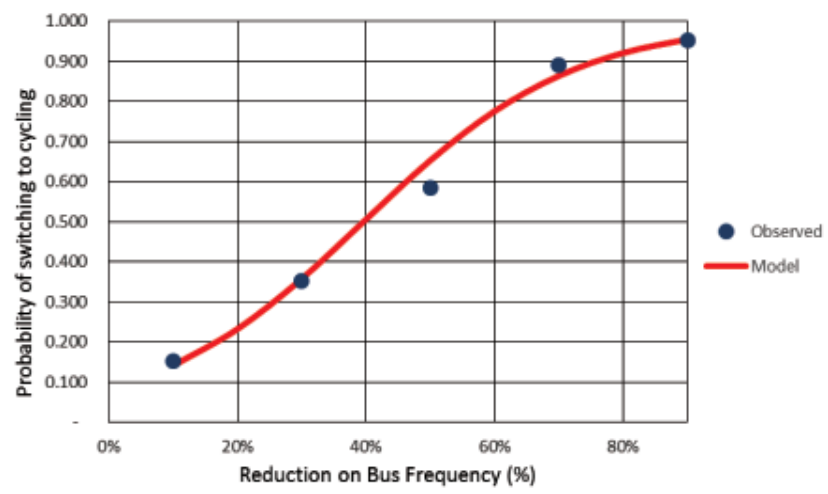

FIGURE 9. Reductions of buses inside UKM that support cycling transport

\section{CONCLUSION}

In this paper, we study the factors that encourage postgraduate students for using private cars and motorcycle also the factors that encourage students using bus. We use logit method for analyses the data that we obtained it from the questionnaire. The postgraduate students in UKM is a good sample and 
effective sample to do good shifting from private car and bus to use bicycle. The most effectiveness factor which influence on students and make them prefer using bus is free charging factor with percentage $23.6 \%$. The effective factor in shifting cars user and motorcycles is imposing fees on parking and limiting the space for parking. Decrease in number of buses and imposing fees on buses have high effectiveness in switching bus user. Our suggestions are limiting parking space and imposing parking fees because in our survey we cleared that most of postgraduate students affected on these factors and accept shifting from car and motorcycle mode to bicycle mode. For students who using bus inside campus the travel time and cost is most important factors on student's mode choice so if UKM decreases bus frequency (number of buses inside campus) this will make students prefer using bicycle mode also imposing fees on bus inside the campus will encourage bus users to use bicycle also Availability of stations in front of each hostel and nearby KTM stations and faculties to borrow or rent bicycles for going to other places on campus provided by employers and community organizations will encourage some postgraduate students to change their mode.

\section{REFERENCE}

Anderson, L., Schnor, P., Schroll, M. \& Hein, H. 2000. Allcause mortality associated with physical activity during leisure time, work, sports, and cycling to work. Arch. Intern. Med 160: 1621-1628.

Abdullah, N., Riza A. R. and Amiruddin, I. 2007. Effect of transportation policies on modal shift from private car to public transport in Malaysia. Journal of applied Sciences 7(7): 1013-1018.

Austroads. 2005. The Australian National Cycling Strategy 2005-1010. Austroads, Sydney. Retrieved from /http:// www.austroads.com .au/documents/ The Australian National Cycling Strategy 2005-2010. Pdfs. Retrieved on: 17 January, 2008.

Bassett, D., Pucher, J., Buehler, R., Thompson, D. \& Crouter, S. 2008. Walking, cycling, and obesity rates in Europe, North America and Australia. J. Phys. Act. Health 5: 795-814.

Caulfield, B. \& Leahy, J. 2011. Learning to cycle again: examining the benefits of providing tax-free loans to purchase new bicycles. Research in Transportation Business \& Management 2: 42-47.

Sahar Abd Ali Dawood* \& Riza Atiq bin O.K. Rahmat Department of Civil Engineering

Faculty of Engineering and Built Environment

Universiti Kebangsaan Malaysia

43600 UKM Bangi, Selangor D.E.

Malaysia
Gatersleben, B. \& Appleton, K.M. 2007. Contemplating cycling to work: Attitudes and perceptions in different stages of change. Transportation Research Part A 41: 302-312.

Jensen, M. 1999. Passion and Heart in Transport-A sociological analysis on transport behavior. Transport Policy 6: 19-33.

Knowles, R.D. 2006. Transport Shaping Space. Differential collapse in time-space. Journal of Transport Geography 14: 407-425.

Pucher, J., Komanoff, C. \& Schimek, P.1999. Bicycling renaissance in North America? Recent trends and alternatives policies to promote bicycling. Transportation Research Part A 33: 625-654.

PPS. 2009. Universiti Kebangsaan Malaysia, 43600 Bandar Baru Bangi, Selangor, Malaysia. Research 25(6): 433438

Piet, R. 2001. Biking and walking: the position of nonmotorized transport modes in transport systems. Tinbergen Institute Discussion Paper TI 2001-111/3.

Woodcock, J, Banister, D, Edwards, P, Prentice, A.M \& Roberts, I. 2007. Energy and transport. The Lancet 370: 1078-1088.

Walsh, C., Jakeman, P., Moles, R. \& Regan, B.O. 2008. A Comparison of carbon dioxide emissions associated with motorized transport modes and cycling in Ireland. Transportation Research Part D 13: 392-399.

Watson, J. 2001. How to Determine a Sample Size: Tipsheet\#60, University Who Europe. 2011 .Health economic assessment tools (HEAT) for walking and cycling: Economic assessment of transport infrastructure and policies. Geneva: World Health Organization.

Xinhua News Agency. 2007. Half of urban residents choose bicycle for commuting. Retrieved on: 4 January 2007. http://www.china.org.cn/english/China/194908.htm.

Axler, R., Chang, W., Gan, J. \& Kembhavi, S. 2006. Out of cars and onto bikes: Encouraging a modal shift from cars to bicycles at the University of Toronto. Applied Research Seminar, 2005-2006.

Yazida, M. R. Mat., Ismail, R. \& Atiqa, R. 2011. The Use of non-motorized for sustainable transportation in Malaysia. Procedia Engineering 20: 125-134.

*Corresponding author; email: saharsnd@yahoo.com

Received Date: $1^{\text {st }}$ March 2014

Accepted Date: $30^{\text {th }}$ March 2015 